\author{
Jacek Batóg \\ Krzysztof Dmytrów
}

\title{
Ekonometryczna analiza produktywności kapitału w krajach Unii Europejskiej
}

\section{Streszczenie}

W artykule przedstawiono wyniki analizy kształtowania się produktywności kapitału w wybranych krajach Unii Europejskiej w latach 2000-2014. Na podstawie jednoczynnikowej funkcji produkcji obliczone zostały zmiany tej zmiennej z wykorzystaniem zarówno danych w postaci szeregów czasowych, jak i danych przekrojowych. Zastosowane narzędzie badawcze pozwoliło na określenie prawidłowości występujących dla poszczególnych krajów oraz w całej Unii Europejskiej. Do najważniejszych zaobserwowanych prawidłowości należą istotny wpływ kryzysu gospodarczego, mającego początek w 2008 r., na kształtowanie się spadkowego trendu produktywności kapitału w krajach Unii Europejskiej oraz występowanie znaczących różnic tej wielkości w ujęciu międzynarodowym. Sformułowane wnioski mogą stanowić przesłanki dla inwestorów, których decyzje oparte są często na analizie zwrotu z zainwestowanego kapitału, a w szerszym ujęciu mogą stanowić informację o przyszłych kierunkach przepływu kapitału i w konsekwencji o zmianach poziomu zatrudnienia w Unii Europejskiej.

Słowa kluczowe: produktywność kapitału, funkcja produkcji, Unia Europejska, modelowanie ekonometryczne.

Klasyfikacja JEL: C51, E23, D24, O47.

Jacek Batóg, Uniwersytet Szczeciński, Wydział Nauk Ekonomicznych i Zarządzania, Instytut Ekonometrii i Statystyki, Katedra Ekonometrii, ul. Mickiewicza 64, 71-101 Szczecin, e-mail: jacek.batog@usz.edu.pl

Krzysztof Dmytrów, Uniwersytet Szczeciński, Wydział Nauk Ekonomicznych i Zarządzania, Instytut Ekonometrii i Statystyki, Katedra Badań Operacyjnych i Zastosowań Matematyki w Ekonomii, ul. Mickiewicza 64, 71-101 Szczecin, e-mail: krzysztof.dmytrow@usz.edu.pl 


\section{Wprowadzenie}

Jedno z kluczowych pytań badawczych formułowanych w obszarze makroekonomii dotyczy przyczyn wzrostu gospodarczego. Poszukuje się w tym przypadku przede wszystkim czynników o uniwersalnym charakterze, odznaczających się stałością zarówno w czasie, jak i w przestrzeni. W większości modeli wzrostu gospodarczego podstawowym czynnikiem tego wzrostu jest akumulacja kapitału rzeczowego. W modelach neoklasycznych przyjmuje się założenie malejącej krańcowej produktywności tego kapitału, przy jednoczesnej egzogeniczności zasobów pracy oraz postępu technicznego. W modelach wskazujących na endogeniczny charakter wzrostu gospodarczego założenie to jest uchylane ${ }^{1}$, a ich twórcy wskazują zróżnicowane czynniki powodujące dodatnie efekty skali poszczególnych rodzajów kapitału [Batóg 2010]. Istotna rola kapitału rzeczowego podkreślana jest również w teoriach rozwoju regionalnego, według których niski zasób i wysoki zwrot z kapitału w krajach mniej rozwiniętych, w połączeniu z malejącą produktywnością kapitału w krajach bardziej rozwiniętych, jest główną przyczyną jego przepływu oraz szybszego wzrostu gospodarczego tych pierwszych ${ }^{2}$. Jeżeli zjawisko to ma charakter długookresowy, to powinno prowadzić do zbieżności łącznej produktywności czynników produkcji oraz konwergencji realnej [Tsionas 2000, s. 297]. Warto jednak zauważyć, że jeżeli główną determinantą konwergencji realnej jest technologia, a nie kapitał, to obserwujemy wówczas wyłącznie konwergencję dochodową o charakterze klubowym [Nowak 2006, s. 253].

Precyzyjne określenie relacji między poziomem i zmianami kapitału rzeczowego a wzrostem gospodarczym nie jest zadaniem łatwym. Nie tylko ze względu na trudności związane z konstrukcją odpowiednich modeli, lecz również z powodu ograniczeń występujących w procesie pomiaru produktywności kapitału. O ile jest to stosunkowo mało skomplikowane na poziomie firm, o tyle zdecydowanie więcej problemów spotykamy w tym zakresie na poziomie sektorowym, a największe trudności pojawiają się w przypadku pomiaru dokonywanego w skali całej gospodarki $\left[\right.$ Technology... 1998, s. 44] ${ }^{3}$.

Znaczenie kapitału rzeczowego należy rozpatrywać w dwóch aspektach pierwszy to istniejący zasób kapitału, a drugi jego produktywność. W pierwszym przypadku obserwujemy w krajach Unii Europejskiej stały wzrost. Średnie tempo zmian w latach 2000-2014 dla całej UE wyniosło 3,3\%, a w poszczególnych

${ }^{1}$ Podkreśla się m.in., że zmiany zasobów kapitału rzeczowego determinują szybkość postępu technicznego, który jest głównym czynnikiem wzrostu gospodarczego [Boskin i Lau 2000, s. 3].

${ }^{2}$ Zależności te nie zawsze znajdują jednak potwierdzenie w wynikach prowadzonych badań zob. np. [Gourinchas i Jeanne 2013].

${ }^{3}$ Zjawisko to odnosi się również do pomiaru wydajności pracy. 
krajach wahało się od 2,4\% dla Niemiec do 9,9\% w przypadku Estonii. Nieco trudniej jest określić produktywność tego czynnika produkcji. W tym celu najczęściej wykorzystuje się funkcję produkcji. To narzędzie ekonometryczne zostało również zastosowane w niniejszym badaniu. Podstawowym celem pracy była analiza kształtowania się produktywności kapitału rzeczowego (niefinansowego) w krajach Unii Europejskiej w latach 2000-2014 ${ }^{4}$. Skonstruowane modele pozwoliły ocenić nie tylko, jakie tendencje obserwujemy w badanym okresie w poszczególnych krajach, lecz również zmianę poziomu produktywności kapitału w całej Unii Europejskiej, wskazując jednocześnie wpływ ostatniego kryzysu gospodarczego na to zjawisko. Opierając się na wykorzystanych narzędziach badawczych, weryfikacji poddano dwie hipotezy. Pierwsza zakłada, że kraje Unii Europejskiej charakteryzuje zróżnicowanie produktywności niefinansowego kapitału rzeczowego oraz, jak wskazuje neoklasyczna teoria wzrostu, poziom tej zmiennej jest wyższy w grupie krajów mniej rozwiniętych, posiadających niższy poziom kapitału przypadającego na jednego zatrudnionego. Druga hipoteza jest odzwierciedleniem endogenicznych teorii wzrostu i zakłada, że wyższą dynamiką wzrostu kapitału rzeczowego odznaczają się kraje o wyższym poziomie jego produktywności.

\section{Metoda badawcza}

Podstawowym narzędziem badawczym zastosowanym w pracy była jednoczynnikowa funkcja produkcji w ujęciu dynamicznym i przekrojowym ${ }^{5}$. Analiza w ujęciu dynamicznym pozwoliła na zbadanie, jak kształtowała się produktywność niefinansowego majątku trwałego w poszczególnych państwach Unii Europejskiej, a ujęcie przekrojowe umożliwiło przeprowadzenie analizy dla całej UE w badanym okresie. Funkcja produkcji w ujęciu dynamicznym ma postać:

$$
W D B_{i t}=\alpha_{0 i} \cdot N M T_{i t}^{\alpha} 1_{1 i} \cdot e^{u_{i t}},
$$

gdzie:

$W D B_{i t}$ - wartość dodana brutto w $i$-tym państwie w $t$-tym roku,

$N M T_{i t}$ - niefinansowy majątek trwały w $i$-tym państwie w $t$-tym roku,

$\alpha_{1 i}$ - produktywność majątku trwałego w $i$-tym państwie rozumiana jako jego elastyczność.

${ }^{4}$ Obszerne studium badawcze dotyczące weryfikacji neoklasycznej hipotezy o malejącej krańcowej produktywności kapitału oraz wyjaśniające różnice w poziomie tej zmiennej występujące w próbie 84 krajów w okresie 1980-2011 stanowi praca [Nell i Thirlwall 2014].

5 Por. model zaproponowany w pracy [Nell i Thirlwall 2014, s. 12], w którym krańcowa produktywność kapitału jest traktowana jako zmienna zależna, oraz metodologię rachunku produktywności KLEMS stosowaną w Unii Europejskiej [Jäger 2016]. 
Szacując model dany równaniem (1) należy pamiętać, że występowanie zbliżonych trendów obu zmiennych może powodować efekt w postaci regresji pozornej. W celu identyfikacji tego zjawiska sprawdzono, jak zachowują się rozważane modele po wprowadzeniu zmiennej czasowej $t$. $\mathrm{Z}$ dwoma wyjątkami (dla Danii i Grecji), wprowadzenie zmiennej czasowej nie poprawiło wyników, a często wręcz je pogorszyło, powodując dodatkowo występowanie autokorelacji składnika losowego (Szwecja, Polska).

Funkcję produkcji w ujęciu przekrojowym przedstawia równanie:

$$
W D B_{t i}=\alpha_{0 t} \cdot N M T_{t i}^{\alpha} 1 t \cdot e^{u_{t i}},
$$

gdzie:

$W D B_{t i}$ - wartość dodana brutto $\mathrm{w} t$-tym roku w $i$-tym państwie,

$N M T_{t i}$ - niefinansowy majątek trwały w $t$-tym roku w $i$-tym państwie,

$\alpha_{1 t}$ - produktywność majątku trwałego w $t$-tym roku rozumiana jako jego elastyczność.

Należy zaznaczyć, że klasyczna funkcja produkcji, oprócz badania produktywności majątku trwałego, umożliwia także ocenę produktywności zatrudnienia. Podczas prowadzonych analiz okazało się jednak, że wprowadzenie do modelu zatrudnienia spowodowało znaczne pogorszenie jakości modeli, co wynikało przede wszystkim ze współliniowości tych zmiennych oraz zmiany tendencji kształtowania się zatrudnienia w okresie pokryzysowym.

\section{Wyniki empiryczne}

Dane wykorzystane w badaniu dotyczą 21 państw Unii Europejskiej i obejmują okres 2000-2014. Ich źródłem jest baza danych Eurostatu. Z powodu występujących braków danych w analizach nie zostały uwzględnione: Bułgaria, Chorwacja, Hiszpania, Irlandia, Malta, Rumunia oraz Słowacja. Wartość dodana brutto pochodziła $\mathrm{z}$ tablicy „Gross value added and income by $\mathrm{A}^{*} 10$ industry breakdowns" (http://appsso.eurostat.ec.europa.eu/nui/submitViewTableAction.do, data dostępu: 11.01.2017), a wartość niefinansowego majątku trwałego - z tablicy „Balance sheets for non-financial assets” (http://appsso.eurostat.ec.europa.eu/nui/ submitViewTableAction.do, data dostępu: 11.01.2017).

W pierwszej kolejności przeanalizowano produktywność niefinansowych aktywów trwałych za pomocą modelu opisanego równaniem (1) w poszczególnych państwach w latach 2000-2014. Oceny parametru $\alpha_{1 i}$ dla poszczególnych państw przedstawiono na rys. 1. 


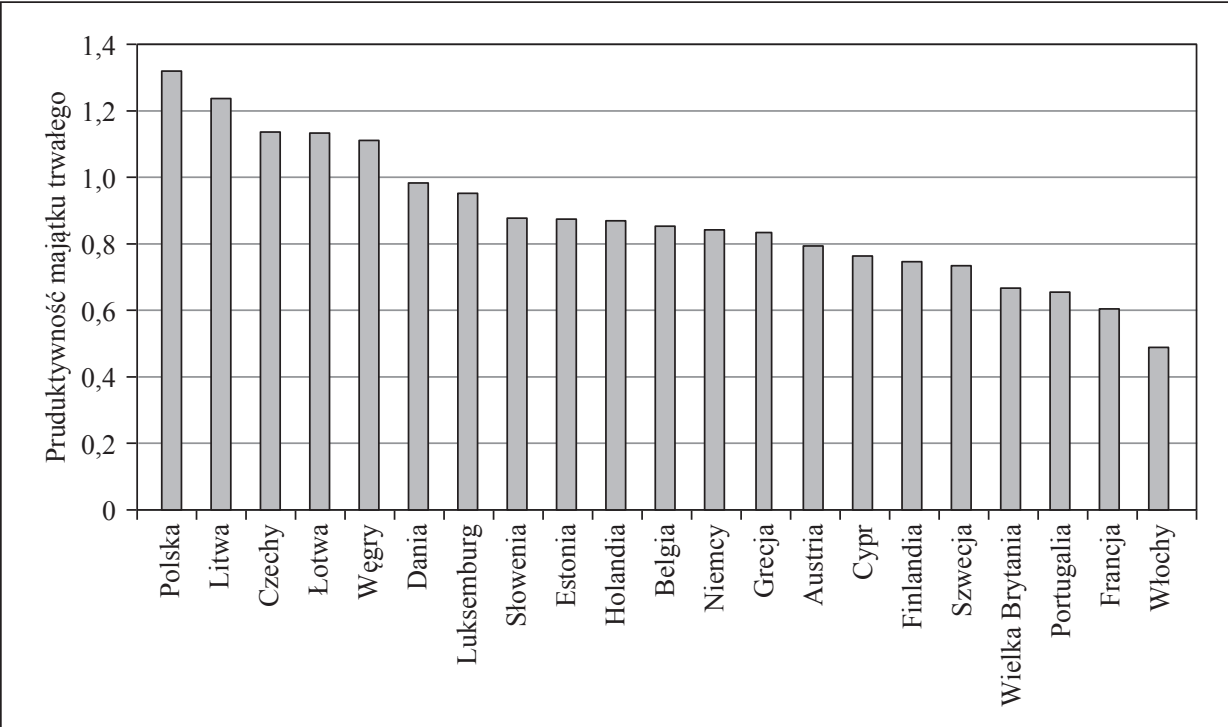

Rys. 1. Produktywność niefinansowego majątku trwałego w krajach Unii Europejskiej w latach 2000-2014

Źródło: obliczenia i opracowanie własne na podstawie danych Eurostatu.

Oceny parametrów $\alpha_{1 i}$ wraz z miarami pozwalającymi ocenić istotność parametrów strukturalnych, stopień dopasowania modeli do danych empirycznych oraz występowanie autokorelacji składnika losowego przedstawiono w tabeli 1.

Uzyskane wyniki potwierdzają teorię mówiącą o wyższej produktywności majątku trwałego w krajach niżej rozwiniętych (najwyższą produktywność zaobserwowano w Polsce, Litwie, Czechach, Łotwie i na Węgrzech, a najniższą - we Włoszech, Francji, Portugalii, Wielkiej Brytanii i Szwecji). W Polsce była ona w badanym okresie najwyższa - zwiększenie zasobów niefinansowego majątku trwałego o $1 \%$ powodowało przeciętny wzrost wartości dodanej brutto o 1,32\%. We Włoszech z kolei jednoprocentowy wzrost tej zmiennej powodował przeciętny wzrost wartości dodanej brutto o niecałe $0,49 \%$. Możemy zauważyć, że w poszczególnych państwach Unii Europejskiej w badanym okresie występowało bardzo duże zróżnicowanie produktywności niefinansowego majątku trwałego ${ }^{6}$. Parametry strukturalne wszystkich przedstawionych modeli były istotne statystycznie.

${ }^{6}$ Jak wskazują dotychczasowe wyniki badań dotyczących przyczyn międzynarodowego zróżnicowania produktywności kapitału, jest ono przede wszystkim skutkiem różnic w poziomie: edukacji, wydatków rządowych, położenia geograficznego, dynamiki eksportu, otwartości gospodarki, wolności politycznej oraz makroekonomicznej stabilności [Nell i Thirlwall 2014]. 
Dopasowanie modeli było wysokie i zawierało się w przedziale od $72 \%$ dla Grecji do 99,3\% dla Belgii. Niestety, w sześciu przypadkach występowała autokorelacja składnika losowego (dla Czech, Grecji, Węgier, Słowenii oraz Wielkiej Brytanii). Także w dziewięciu na 21 przypadków wartość współczynnika determinacji liniowej była wyższa od wartości statystyki Durbina-Watsona, co może sugerować istnienie regresji pozornej.

Tabela 1. Podstawowe statystyki dla modelu (1)

\begin{tabular}{|l|c|c|c|c|c|c|}
\hline \multicolumn{1}{|c|}{ Kraj } & $\hat{\alpha}_{1 i}$ & $D\left(\hat{\alpha}_{1 i}\right)$ & $t$ & Wartość $p$ & $R^{2}(\mathrm{w} \%)$ & D-W \\
\hline Austria & 0,794 & 0,027 & 29,246 & 0,0000 & 98,50 & 0,803 \\
\hline Belgia & 0,853 & 0,020 & 43,618 & 0,0000 & 99,32 & 1,012 \\
\hline Cypr & 0,764 & 0,023 & 32,669 & 0,0000 & 98,80 & 0,999 \\
\hline Czechy & 1,136 & 0,028 & 40,339 & 0,0000 & 99,21 & 0,550 \\
\hline Dania & 0,983 & 0,033 & 29,747 & 0,0000 & 98,55 & 0,722 \\
\hline Estonia & 0,874 & 0,034 & 25,584 & 0,0000 & 98,05 & 1,279 \\
\hline Finlandia & 0,747 & 0,038 & 19,812 & 0,0000 & 96,79 & 1,266 \\
\hline Francja & 0,604 & 0,015 & 40,439 & 0,0000 & 99,21 & 1,040 \\
\hline Grecja & 0,833 & 0,145 & 5,765 & 0,0001 & 71,88 & 0,163 \\
\hline Holandia & 0,869 & 0,037 & 23,249 & 0,0000 & 97,65 & 1,087 \\
\hline Litwa & 1,237 & 0,035 & 35,274 & 0,0000 & 98,97 & 1,439 \\
\hline Luksemburg & 0,952 & 0,040 & 23,717 & 0,0000 & 97,74 & 1,143 \\
\hline Łotwa & 1,133 & 0,073 & 15,614 & 0,0000 & 94,94 & 0,896 \\
\hline Niemcy & 0,842 & 0,043 & 19,705 & 0,0000 & 96,76 & 1,265 \\
\hline Polska & 1,320 & 0,051 & 25,916 & 0,0000 & 98,10 & 1,235 \\
\hline Portugalia & 0,654 & 0,027 & 23,815 & 0,0000 & 97,76 & 1,057 \\
\hline Słowenia & 0,877 & 0,062 & 14,113 & 0,0000 & 93,87 & 0,461 \\
\hline Szwecja & 0,734 & 0,037 & 19,827 & 0,0000 & 96,80 & 1,383 \\
\hline Węgry & 1,111 & 0,082 & 13,618 & 0,0000 & 93,45 & 0,436 \\
\hline Wielka Brytania & 0,667 & 0,097 & 6,880 & 0,0000 & 78,45 & 0,635 \\
\hline Włochy & 0,488 & 0,044 & 11,126 & 0,0000 & 90,50 & 0,423 \\
\hline Oznaczena & $0 c 06$ \\
\hline
\end{tabular}

Oznaczenia: $\hat{\alpha}_{1 i}$ - ocena produktywności majątku trwałego w $i$-tym państwie, $D\left(\hat{\alpha}_{1 i}\right)$ - błąd standardowy, $t$ - wartość statystyki $t$-Studenta, $R^{2}$ - współczynnik determinacji liniowej,

D-W - wartość statystyki Durbina-Watsona.

Źródło: obliczenia i opracowanie własne na podstawie danych Eurostatu.

Interesujące okazało się również badanie zmian produktywności niefinansowego majątku trwałego w analizowanych państwach Unii Europejskiej w kolejnych latach. Uzyskane wyniki zobrazowano na rys. 2. 


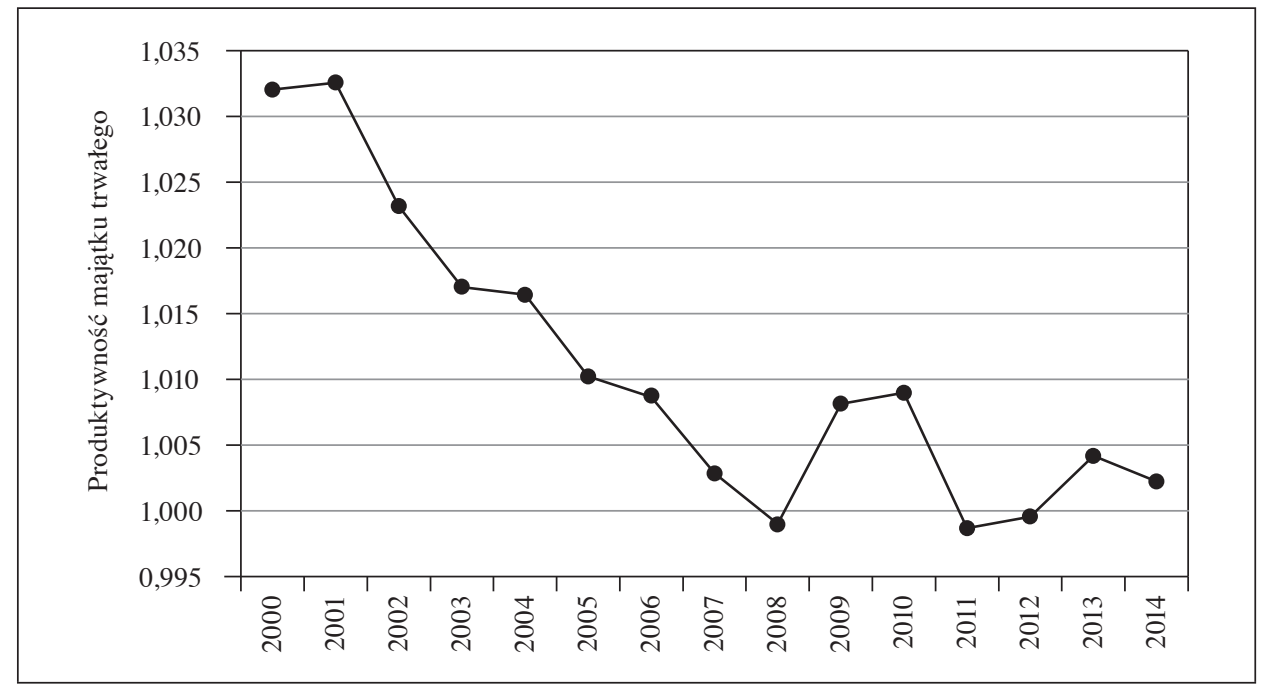

Rys. 2. Produktywność niefinansowego majątku trwałego w Unii Europejskiej w latach 2000-2014

Źródło: obliczenia i opracowanie własne na podstawie danych Eurostatu.

Oceny parametrów $\alpha_{1 t}$ wraz z miarami pozwalającymi ocenić istotność parametrów strukturalnych oraz stopień dopasowania modeli do danych empirycznych przedstawiono w tabeli 2.

Analizując wyniki przedstawione na rys. 2 możemy stwierdzić, że w badanym okresie produktywność majątku trwałego malała, lecz jej zmiany nie były znaczące (w 2001 r. ocena parametru $\alpha_{1 t}$ była najwyższa i wyniosła 1,033, a w 2011 r. najniższa i równa 0,999) ${ }^{7}$. Oznacza to, że w 2001 r. w Unii Europejskiej przyrost niefinansowego majątku trwałego o $1 \%$ powodował średni przyrost wartości dodanej brutto o 1,03\%, a w 2011 r. - o niecały procent. Widać także, że do 2008 r. produktywność ta w niewielkim stopniu malała, a po tym roku oscylowała wokół wartości 1,0058. Podobnie jak dla ujęcia dynamicznego, także w ujęciu przekrojowym wszystkie parametry strukturalne były statystycznie istotne, a dopasowanie modeli wynosiło ponad $97 \%$.

7 Jednocześnie obserwowana była lustrzana tendencja w przypadku TFP mierzonej wartością oceny wyrazu wolnego, która do 2008 r. rosła, a następnie ustabilizowała się na pewnym poziomie.

${ }^{8}$ Uzyskane wyniki są rozbieżne z wynikami zaprezentowanymi w pracy [Gehringer 2013], w której wskazuje się pozytywny wpływ liberalizacji przepływów finansowych, będącej skutkiem integracji europejskiej, na wzrost gospodarczy i wzrost produktywności kapitału rzeczowego. Wykazują jednocześnie podobieństwo do rezultatów uzyskanych w pracy [Montes-Solla, Faiña i Lopez-Rodriguez 2015], w której stwierdzono spadek produktywności kapitału w Hiszpanii w latach 1989-2010. 
Tabela 2. Podstawowe statystyki dla modelu (2)

\begin{tabular}{|c|c|c|c|c|c|}
\hline Rok & $\hat{\alpha}_{1 t}$ & $D\left(\hat{\alpha}_{1 t}\right)$ & $t$ & Wartość $p$ & $R^{2}(\mathrm{w} \%)$ \\
\hline 2000 & 1,032 & 0,013 & 80,927 & 0,0000 & 97,12 \\
\hline 2001 & 1,033 & 0,010 & 102,006 & 0,0000 & 97,68 \\
\hline 2002 & 1,023 & 0,009 & 110,307 & 0,0000 & 97,82 \\
\hline 2003 & 1,017 & 0,009 & 114,305 & 0,0000 & 97,87 \\
\hline 2004 & 1,016 & 0,009 & 119,049 & 0,0000 & 97,94 \\
\hline 2005 & 1,010 & 0,008 & 119,024 & 0,0000 & 97,90 \\
\hline 2006 & 1,009 & 0,010 & 99,754 & 0,0000 & 97,45 \\
\hline 2007 & 1,003 & 0,010 & 100,004 & 0,0000 & 97,39 \\
\hline 2008 & 0,999 & 0,010 & 98,712 & 0,0000 & 97,31 \\
\hline 2009 & 1,008 & 0,010 & 96,793 & 0,0000 & 97,30 \\
\hline 2010 & 1,009 & 0,011 & 94,283 & 0,0000 & 97,25 \\
\hline 2011 & 0,999 & 0,011 & 92,303 & 0,0000 & 97,15 \\
\hline 2012 & 1,000 & 0,011 & 90,261 & 0,0000 & 97,09 \\
\hline 2013 & 1,004 & 0,011 & 95,462 & 0,0000 & 97,24 \\
\hline 2014 & 1,002 & 0,009 & 111,647 & 0,0000 & 97,64 \\
\hline
\end{tabular}

Oznaczenia: $\hat{\alpha}_{1 t}$ - ocena produktywności majątku trwałego w $t$-tym roku, $D\left(\hat{\alpha}_{1 t}\right)$ - błąd standardowy, $t$ - wartość statystyki $t$-Studenta, $R^{2}$ - współczynnik determinacji liniowej. Źródło: obliczenia i opracowanie własne na podstawie danych Eurostatu.

Następnie zbadano poziom niefinansowego majątku trwałego przypadającego na jednego zatrudnionego (czyli techniczne uzbrojenie pracy) w ostatnim badanym roku. Pozwoliło to wyróżnić dwie grupy państw - pierwszą utworzyły państwa o wartości technicznego uzbrojenia pracy poniżej 200 tys. euro na zatrudnionego, a drugą grupę - państwa o wartości tego wskaźnika powyżej 200 tys. euro na zatrudnionego (zob. tabela 3).

W drugiej grupie występowały państwa będące na wyższym poziomie rozwoju społeczno-ekonomicznego, z jednym wyjątkiem, który stanowiła Wielka Brytania. Spowodowane jest to specyfiką brytyjskiej gospodarki, w której znacznie większą rolę odgrywają aktywa finansowe. Udział aktywów finansowych w aktywach ogółem w Wielkiej Brytanii był największy (poza niewielkimi i raczej nietypowymi gospodarkami Luksemburga i Cypru) i wynosił w 2014 r. ponad 88\% (dla przykładu w gospodarkach podobnej wielkości - niemieckiej, francuskiej i włoskiej - udziały te wynosiły, odpowiednio, 71,3\%, 78\% i 68,4\%).

Obie grupy państw różniły się zasadniczo pod względem tempa zmian nakładów brutto na środki trwałe. $\mathrm{W}$ tabeli 4 przedstawiono zmianę nakładów brutto na środki trwałe w całym badanym okresie oraz w okresie przedkryzysowym. 
Tabela 3. Państwa Unii Europejskiej według poziomu niefinansowego majątku trwałego przypadającego na jednego zatrudnionego

\begin{tabular}{|c|c|}
\hline Grupa 1 & Grupa 2 \\
\hline Cypr & Austria \\
\hline Czechy & Belgia \\
\hline Estonia & Dania \\
\hline Grecja & Finlandia \\
\hline Litwa & Francja \\
\hline Łotwa & Holandia \\
\hline Polska & Luksemburg \\
\hline Portugalia & Niemcy \\
\hline Słowenia & Szwecja \\
\hline Węgry & Włochy \\
\hline Wielka Brytania & - \\
\hline
\end{tabular}

Źródło: opracowanie własne.

Tabela 4. Względna zmiana nakładów brutto na środki trwałe (w \%)

\begin{tabular}{|c|c|c|}
\hline \multirow{2}{*}{ Grupa } & \multicolumn{2}{|c|}{ Względna zmiana nakładów brutto } \\
\cline { 2 - 3 } & $2008 / 2000$ & $2014 / 2000$ \\
\hline 1 & 141,4 & 73,4 \\
\hline 2 & 38,7 & 38,2 \\
\hline
\end{tabular}

Źródło: opracowanie własne.

Można zauważyć, że od początku badanego okresu do początku kryzysu finansowego nakłady brutto na środki trwałe w pierwszej grupie zwiększyły się o ponad $140 \%$, a w krajach z grupy drugiej wzrost ten kształtował się na poziomie prawie 39\%. Z kolei jeżeli weźmiemy pod uwagę cały badany okres, to okazuje się, że w pierwszej grupie nakłady brutto na środki trwałe zwiększyły się o 73\%, a w grupie drugiej - o 38\%. Świadczy to o tym, że po kryzysie w pierwszej grupie krajów nastąpił znaczący spadek inwestycji w środki trwałe, a w grupie drugiej utrzymywały się one na względnie stałym poziomie.

Interesująco przedstawia się również zależność produktywności majątku trwałego przypadającego na jednego zatrudnionego od jego poziomu (rys. 3). W pierwszej grupie rozważana zależność była ujemna, a w drugiej grupie dodatnia. Potwierdza to teorię malejącej krańcowej produktywności kapitału dla państw o niskim poziomie aktywów oraz teorię wzrostu endogenicznego dla państw o wysokim poziomie aktywów, która zakłada brak malejącej krańcowej wydajności kapitału ze względu na inne czynniki wywołujące dodatnie efekty skali. 


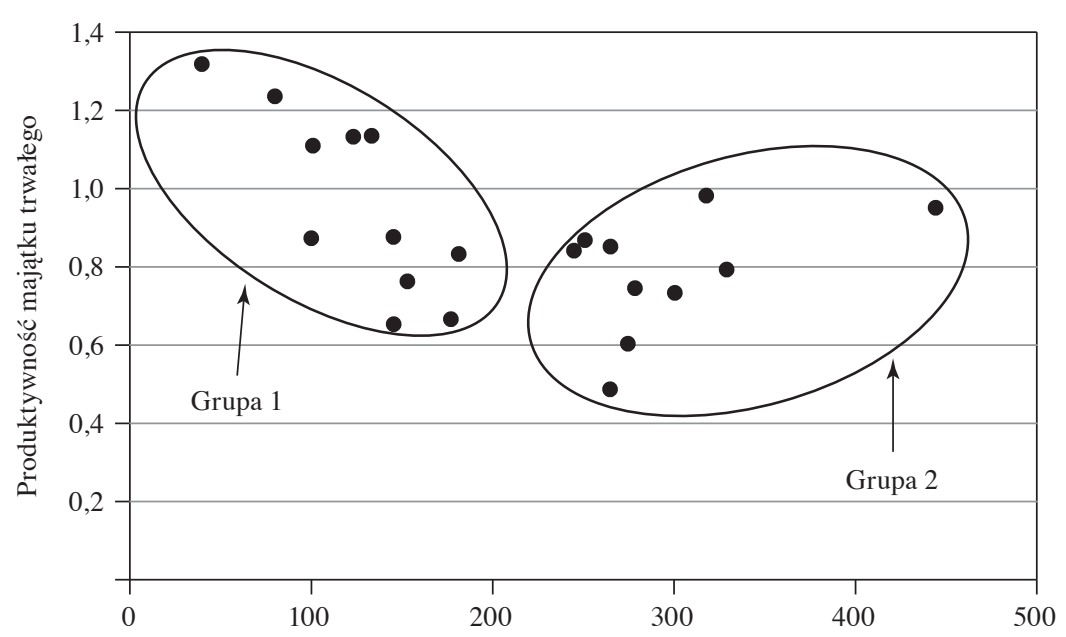

Niefinansowy majątek trwały przypadający na jednego zatrudnionego

Rys. 3. Zależność między produktywnością (2000-2014) a poziomem niefinansowego majątku trwałego przypadającego na jednego zatrudnionego (wartość majątku z 2014 r., w tys. euro) w krajach Unii Europejskiej

Źródło: obliczenia i opracowanie własne na podstawie danych Eurostatu.

Zależność między dynamiką nakładów brutto na środki trwałe a poziomem niefinansowego majątku trwałego przypadającego na jednego zatrudnionego przedstawiono na rys. 4. Ujemna zależność między dynamiką nakładów brutto na środki trwałe a poziomem niefinansowego majątku trwałego przypadającego na jednego zatrudnionego wystąpiła dla pierwszej grupy krajów, co ponownie potwierdza teorię mówiącą o większym napływie kapitału do krajów o jego niskim relatywnym poziomie. $\mathrm{Z}$ kolei $\mathrm{w}$ grupie drugiej zależność ta była dodatnia, co również potwierdza teorię wzrostu endogenicznego. Powyższe wyniki sugerują występowanie innych determinant napływu kapitału w krajach charakteryzujących się wyższą intensywnością kapitałową w porównaniu z krajami, w których obserwujemy niższy poziom kapitału rzeczowego przypadającego na jednego zatrudnionego. Ponieważ jedną z determinant może być koszt pracy, analizie poddano zależność między tą zmienną a dynamiką nakładów brutto na środki trwałe (zob. rys. 5).

W tym przypadku badane kraje Unii Europejskiej również można podzielić na dwie grupy. Pierwszą stanowiły państwa o kosztach pracy poniżej 15 euro za godzinę, a drugą państwa o kosztach pracy powyżej 20 euro za godzinę. 


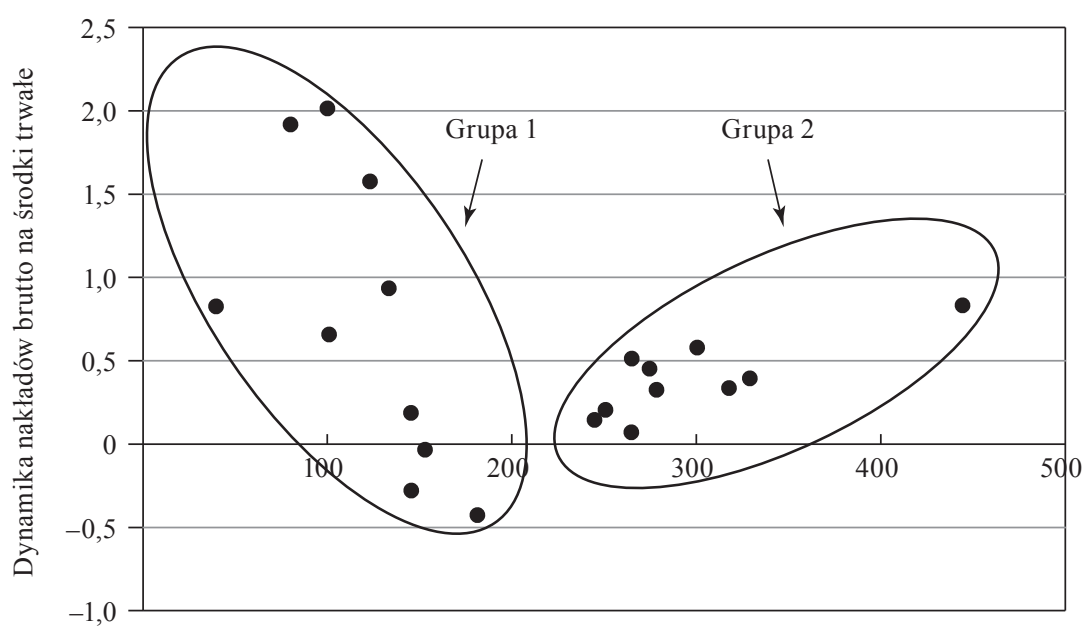

Niefinansowy majątek trwały przypadający na jednego zatrudnionego

Rys. 4. Zależność między dynamiką nakładów brutto na środki trwałe (2000-2014) a poziomem niefinansowego majątku trwałego przypadającego na jednego zatrudnionego (wartość majątku z 2014 r., w tys. euro) w krajach Unii Europejskiej Źródło: obliczenia i opracowanie własne na podstawie danych Eurostatu.

a)

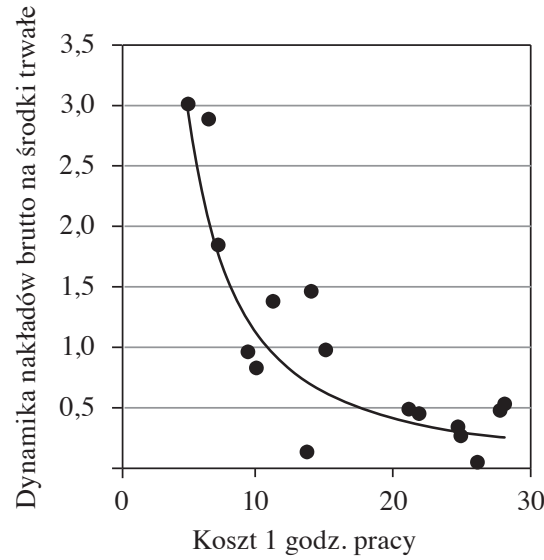

b)

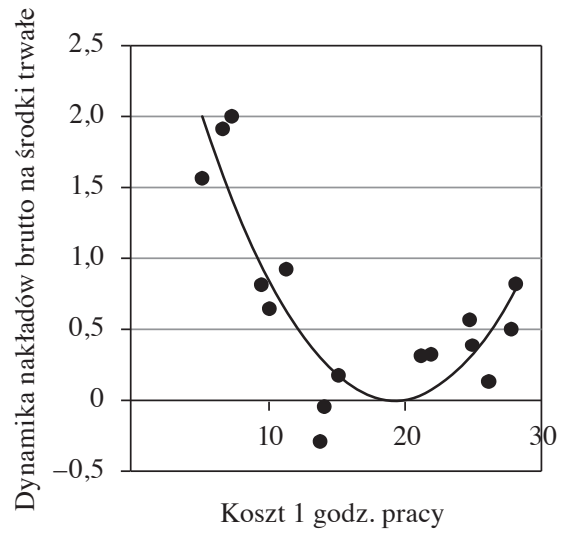

Rys. 5. Zależność między kosztem pracy (w euro, ceny stałe z 2005 r.) a dynamiką nakładów brutto na środki trwałe: a) w latach 2000-2008 i b) w latach 2000-2014 Źródło: obliczenia i opracowanie własne na podstawie danych Eurostatu. 
W latach 2000-2008 widoczna była ujemna zależność między rozpatrywanymi zmiennymi, która następnie na skutek kryzysu gospodarczego została nieco zniekształcona, ponieważ wyższy poziom ryzyka inwestycyjnego spowodował zmniejszenie dynamiki migracji kapitału do krajów o niższym poziomie rozwoju (por. tabela 4).

\section{Wnioski}

W ostatnich kilkunastu latach obserwujemy zmniejszanie się krańcowej produktywności kapitału niefinansowego w krajach Unii Europejskiej. Produktywność ta utrzymuje się jednocześnie na wyższym poziomie w nowych krajach członkowskich, które charakteryzują się również szybszym napływem kapitału rzeczowego oraz niższą wartością bazową. Uzyskane wyniki są zgodne ze sformułowanymi hipotezami badawczymi. Analiza zależności między produktywnością kapitału niefinansowego i jego dynamiką wskazuje na brak tej zależności w przypadku uwzględnienia wszystkich krajów Unii Europejskiej oraz jej występowanie w wydzielonych grupach krajów. Zjawisko to może być tłumaczone m.in. odmiennym poziomem kosztów pracy charakteryzującym poszczególne kraje. Jednocześnie warto zauważyć, że występowanie swego rodzaju klubowej produktywności kapitału wskazuje na odmienną rolę czynników decydujących o zachodzeniu konwergencji realnej. W krajach o niższym poziomie kapitału przypadającego na jednego zatrudnionego decydujące znaczenie mają akumulacja i produktywność kapitału, podczas gdy w grupie krajów o wyższym poziomie rozwoju znaczenie ma przede wszystkim stosowana technologia. Oceniając kształtowanie się produktywności w krajach UE, należy jednocześnie uwzględnić, że wpływ na przedstawione wyniki może mieć wybrany okres analizy, obejmujący spowolnienie wzrostu gospodarczego oraz zmiany przepływu kapitału wywołane ogólnoświatowym kryzysem.

\section{Literatura}

Batóg J. [2010], Konwergencja dochodowa w krajach Unii Europejskiej. Analiza ekonometryczna, Uniwersytet Szczeciński, Rozprawy i Studia, t. 780, Wydawnictwo Naukowe Uniwersytetu Szczecińskiego, Szczecin.

Boskin M.J., Lau L.J. [2000], Generalized Solow-Neutral Technical Progress and Postwar Economic Growth, NBER Working Paper No. 8023, Cambridge.

Gehringer A. [2013], Growth, Productivity and Capital Accumulation: The Effects of Financial Liberalization in the Case of European Integration, ,International Review of Economics and Finance", vol. 25, https://doi.org/10.1016/j.iref.2012.07.015. 
Gourinchas P.O., Jeanne O. [2013], Capital Flows to Developing Countries: The Allocation Puzzle, ,Review of Economic Studies”, vol. 80, nr 4, https://doi.org/10.1093/restud/ rdt004.

Jäger K. [2016], EU KLEMS Growth and Productivity Accounts 2016 Release, Statistical Module, The Conference Board, http://euklems.net/TCB/2016/Metholology_EU\%20 KLEMS_2016.pdf (data dostępu: 11.01.2017).

Montes-Solla P., Faiña Medín J.A., Lopez-Rodriguez J. [2015], Regional Development in Spain 1989-2010: Capital Widening and Productivity Stagnation, Munich Personal RePEc Archive, Paper No. 72921.

Nell K.S., Thirlwall A.P. [2014], Explaining Differences in the Productivity of Capital Across Countries in the Context of 'New' Growth Theory, University of Kent, School of Economics Discussion Papers, KDPE 1412.

Nowak W. [2006], Koncepcje konwergencji w teorii wzrostu gospodarczego, „Nierówności Społeczne a Wzrost Gospodarczy", nr 8.

Technology, Productivity and Job Creation. Best Policy Practices [1998], OECD, Paris.

Tsionas E.G. [2000], Productivity Convergence in Europe, „Eastern Economic Journal”, vol. $23, \mathrm{nr} 3$.

\section{An Econometric Analysis of Capital Productivity in the European Union}

(Abstract)

The paper presents the results of an analysis of capital productivity in the member countries of the European Union in the years 2000-2014. On the basis of a one-factor production function, changes in this variable were calculated for both time series and crosssection data. This enabled the identification of regularities both in particular countries and the EU as a whole. Those regularities included the significant influence of the economic crisis which began in 2008, the attendant blow to capital productivity of capital in the Member States and the large differences in this measure in the international dimension. The paper's conclusions can be used by investors, whose decisions are based on the analysis of returns on invested capital. More generally, they may also inform about the future directions of capital flows and, as a consequence, about changes in EU employment levels.

Keywords: capital productivity, production function, European Union, econometric modelling. 